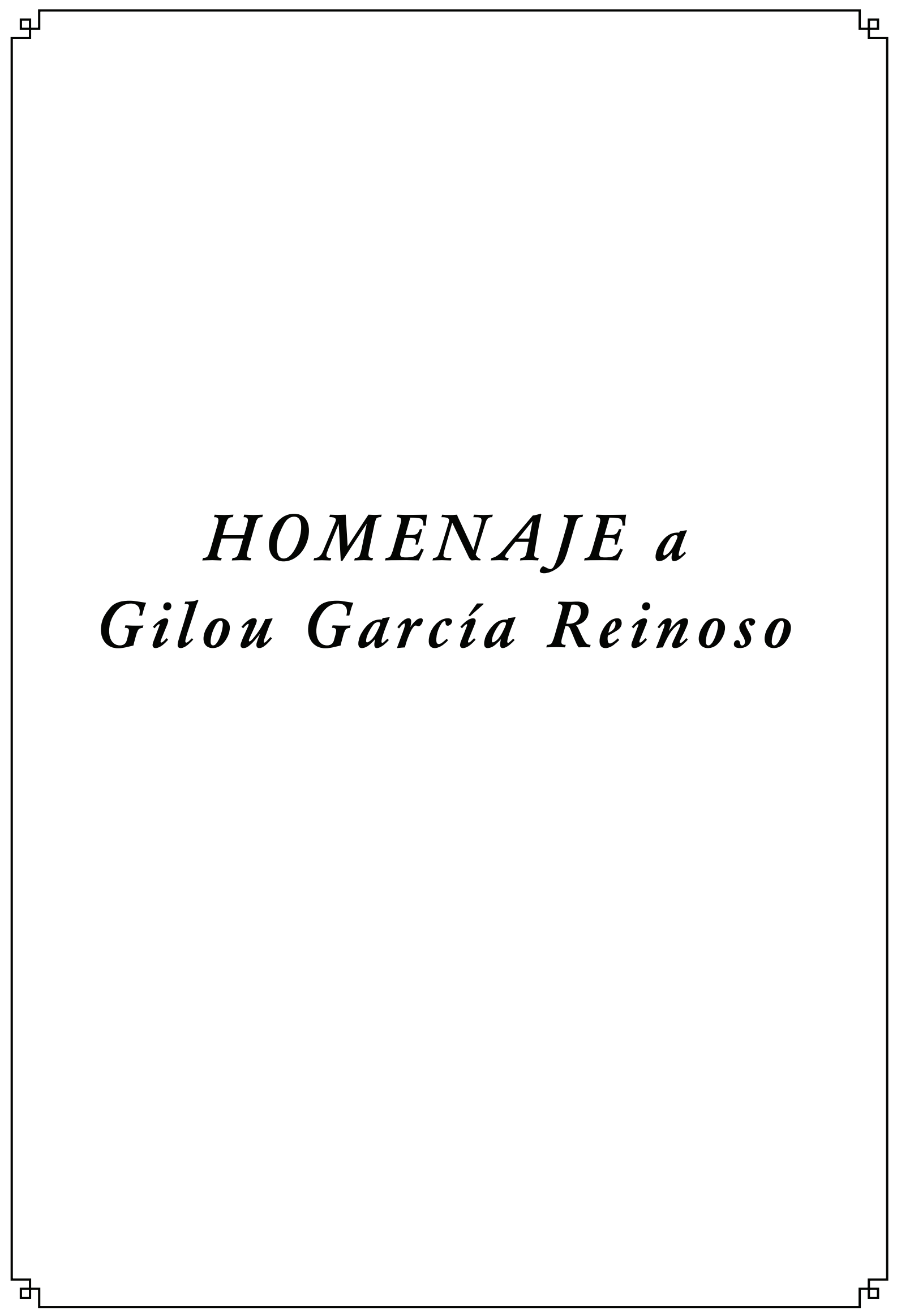





\title{
Lo que Gilou quería que fuera dicho sobre su vida
}

\author{
Juan Carlos Volnovich ${ }^{1}$
}

Hace unos años, pocos a decir verdad, en charla intima le pregunté a Gilou que quería que dijera de ella cuando no estuviera y me dictó lo siguiente:

Nací el 12 de enero de 1926 en Villa Ballester. Tuve un hermano varón, que murió recién nacido, y dos hermanas: Margarita y René. Yo era la menor.

Mi papá - que había peleado en la Primera Guerra Mundial- tenía en Buenos Aires un negocio de ferreteria, la ferreteria Franco-Americana en la calle Suipacha. Eso quiere decir que nací en el seno de una familia de clase media acomodada. Cuando tenía seis años -en 1932- nos mudamos a Niza. Allí vivíamos de la renta de la ferretería.

Tengo muchos recuerdos de mi infancia en Niza. Uno de ellos: parece que siempre tuve mucho carácter y por eso mis padres contaban que en aquella ocasión, cuando un perro me mordió, el perro se murió. El perro se murió, pero yo tuve que recibir una serie de inyecciones muy dolorosas.

Cuando cumplí once años, en 1937, por el temor a la guerra, volvimos a la Argentina. Una vez en Buenos Aires entré al Colegio -no al Liceo Francés- sino al Colegio Franco Argentino, que tenía un arreglo con la embajada de Francia para convalidar los certificados.

A los doce años me enamoré perdidamente de Francois Tronquoi, pero Tronquoi se fue a la guerra. No obstante, antes de partir me declaró su amor. Cuando volvió de la guerra me casé. Tenía veinte años. Estuve nueve años casada con él. Por entonces vivíamos en el mismo edificio -un piso por debajo- que mis cuñados: Nun (Genevive Tronquoi) y Racker. De mi matrimonio con Tronquoi nacieron Michelle y, tres años después, Mariana.

Antes del nacimiento de Mariana había comenzado a estudiar Matemáticas, cuando Ciencias Exactas estaba todavía en la calle Perú. Pero abandoné Matemáticas y entré a la Facultad de Filosofía y Letras. Allí duré tres años, para recién entonces inscribirme en Medicina.

Me analicé un año con Willy Baranger en francés pero, después, el análisis didáctico lo hice con Arminda Aberastury cuando ella acababa de ser nombrada Miembro Didacta. Tengo un recuerdo muy grato de la Negra. Por aquel entonces yo estaba estudiando Medicina, tenía dos hijos chicos y me ganaba la vida trabajando como modista. En ese momento el análisis suponía cuatro veces por semana a altos honorarios pero ante mi situación la Negra me dijo: "Usted no puede pagar esos honorarios" y decidió cobrarme muchísimo menos. Posteriormente, ya de grande, volví a analizarse por un breve período con Serge Leclaire.

\footnotetext{
${ }^{1}$ Médico; Psicoanalista (renunció a la Asociación Psicoanalítica Argentina en 1971 integrando el Grupo Plataforma). Especialista en Psiquiatría Infantil por el Ministerio de Salud Pública de Cuba. Premio Konex. Diploma al Mérito en Psicoanálisis, 2016. Profesor Extraordinario Honorario y Académico Ilustre por la Universidad de Mar del Plata. Doctor Honoris Causa por la Universidad Madres de Plaza de Mayo. Miembro de Honor de la Sociedad de Psicólogos de Cuba. Miembro de Honor de la Asociación Médica Argentina. Ha sido seleccionado por la Unión de Mujeres de la Argentina para recibir la estatuilla Margarita de Ponce por sus aportes a la Teoría de Género.
} 
Cursé los seminarios en el Instituto de Psicoanálisis de la A.P.A., hice una carrera muy rápida como Miembro Adherente, como Miembro Titular, y llegué a ser Miembro Didacta de la Asociación cuando tenía 38 años. Renuncié a la Asociación Psicoanalítica integrando el grupo Plataforma, pero antes, en el año 67, integré el grupo fundador de la Asociación de Psicología y Psicoterapia de Grupo.

Volví a enamorarme. Esta vez de Diego García Reinoso y con él lo tuve a Martín. De modo tal que con la primera sílaba de los nombres de mis hijos: Michelle, Mariana y Martín, logré un "mi mamá".

Mi nombre real es Gilberte Genoveva Royer pero mis maridos me han dado mi nueva identidad. Tronquoi me bautizó Gilou y Diego me dio el García Reinoso.

En la época en que renuncié a la A.P.A. entré a trabajar en la Cátedra de Psicología Médica de la Facultad de Medicina de la UBA. Eso duró hasta la intervención de Ottalagano. La Cátedra de Psicología Médica era un centro que recibía y nucleaba a todo lo más progresista que había en Psicología en ese momento y era enorme la cantidad de gente que trabajaba allí en atención, en asistencia y en investigación. Trabajé en Medicina del Trabajo, dirigí una investigación con los mineros en Salta, y también integré el Centro de Docencia e Investigación de la Coordinadora de Trabajadores de Salud Mental. Todo eso hasta que las amenazas de la Triple A nos empujaron al exilio en 1975. Pudimos elegir París para exiliarnos pero Diego no dominaba el francés y, entonces, nos decidimos por México. Allí trabajé en el Instituto de Medicina del Trabajo de la UNAM (Universidad Autónoma de México) hasta que decidimos regresar, tal vez muy prematuramente, a fines de 1981. El regreso fue muy traumático, todavía estábamos en plena dictadura militar, no teníamos trabajo y nos quedaban muy pocos amigos. Volvimos porque Diego quería volver. Diego decía que si se quedaba en México se moría. Volvimos y se murió.

Lo demás es muy actual: fundé la Sección Argentina de Médicos del Mundo y trabajo desde hace muchos años en la Asamblea Permanente por los Derechos Humanos. Siempre me dediqué a la clínica psicoanalítica.

Buenos Aires, agosto 2018 